\title{
Prospective Model in Public Policy for a Democratic and Equitable Election of Regional Leaders
}

\author{
Suparnyo* \\ Lecturer Faculty of Law, Muria Kudus University
}

The election of regional leaders conducted directly by the community is believed to result in a democratic government. The formed government is expected to be more open, more responsive, and to carry out the aspirations of the people so that it can realize a government that comes from the people, by the people, and for the people. A person can nominate him/herself as a candidate for Regent or Deputy Regent if supported by some residents, by Political Parties or Combined Political Parties. The relatively weak support of the population or political parties or combined political parties has resulted in very few candidates for regent or deputy regent, even only one pair of candidates can occur as in Pati Regency. The study aims to know how the policy in the future (Prospective Model) should be taken so that the single-candidate for Regent or Deputy Regent in a general election does not happen. By using a sociological juridical approach, collecting primary and secondary data, processing and analyzing data, the objective of the study can be reached. The policy that needs to be taken by the government so that in the future there will be no single candidate is by giving obligations to political parties to conduct cadre recruitment to become candidates for regional leaders. Besides, the General Election Commission needs to make a scheme that is easier and more flexible for individual candidates regarding administrative requirements, procedures, and mechanisms for gathering support, and there needs to be a new policy so that the potential

OPEN ACCESS ISSN 2527-9246 (online) ISSN 2338-445X (print)

Edited by:

IImi Usrotin Choiriyah

Reviewed by:

Bambang Kusbandrijo

*Correspondence:

Suparnyo

suparnyo@umk.ac.id

Published: 01 Maret 2020

Citation:

Suparnyo (2020) Prospective Model in Public Policy for a Democratic and Equitable Election of Regional

Leaders.

JKMP (Jurnal Kebijakan dan

Manajemen Publik). 8:1.

doi: $10.21070 / j k m p . v 8 i 1.676$ for a single-candidate can be eliminated or not occur.

Keywords: Prospective Model, Regional Leader Election, Democratic

\section{INTRODUCTION}

The science of public policy is relatively new, and public policy shows its progress in the United States after the Second World War since the quality of political life had greatly benefited from public policy (Peter deLeon, Danielle M. Vogenbeck, 4). The approach that needs to be taken by Public policy is through the way of analyzing future policies so that it can complement or replace traditional forms of policy analysis. Danielle and Vogenbeck (2014)

Lasswell justifies that a policy must be dedicated to a democratic future to achieve the prosperity of all human dignity Torgerson (1986). The public policy issued by the government is intended to create a prosperous society. The Government of Indonesia in regulating the political system is also expected to realize justice and prosperity. Fischer et al. (2007) Among the various policies issued by the government are policies in political field, namely in the form of a law which is in this case the Act Number 10 of 2016 concerning the Second Amendment to Act Number 1 of 2015 concerning Establishment of Government Regulations in Lieu of Law 
Number 1 Year 2014 concerning the Election of Governors, Regents and Mayors becoming Acts (hereinafter referred to as the Act on Regional Leader's Election).The Act on Election was issued to realize the election of the Governor and Deputy Governor, Regent and Deputy Regent, and Mayor and Deputy Mayor in a democratic manner and strengthen efficient and effective local governance. The democratic election's mechanism is held in the context of the implementation of people's sovereignty in the provinces and regencies/districts. The general explanation of the Act on Regional Leader Election points out that the election of the Governor/deputy governor, regent/deputy regent, and mayor/deputy mayor directly elected and which is a package shows that the costs incurred by the state or candidate pairs are very large, so that there will be a great potential to cause conflict, corruption, and ineffective and inefficient governance.

Article 1 number 4 of the Act of Regional Leader Election stipulates that the candidates for regent and deputy regent, candidates for mayor and candidates for deputy mayor are election participants proposed by political parties, a combination of political parties or individuals registered or to be registered in the regency/city's general election commission. The Regional Leader Election (Pilkada) is held to elect leaders directly conducted by the people in one region. This leader is chosen by local residents who meet the requirements based on applicable laws and regulations. The Regional Leader Election is held to elect the governor and deputy governor or regent/mayor and deputy regent/deputy mayor. This election is not regulated in the 1945 Constitution, but by the Acts, among others are Act Number 32 of 2004, Act Number 22 of 2007, and Act Number 6 of 2016. The importance of regional leader election is enabling to get regional leaders who have quality and accountability; can create political stability and governance effectiveness at the local level; enable to improve the quality of national leadership because more opportunities are open for the emergence of national leaders from low class and or regions. Sofyan (2013)

Election of regional leaders sometimes causes problems, among others because the regeneration to prepare candidates for leaders from the party is very slow, additionally, the conditions set for prospective regional leaders are very heavy. With such political party circumstances and hard conditions resulting in a minimal number of regional leaders, there is even only one pair of a candidate, such as in Pati Regency in the 2017 Regional Leader Election. The problem that needs to be resolved is why supporters of empty boxes filed a lawsuit over the nomination of a single leader candidate and how the prospective future policy model must be developed so that there will be no more election of candidates for regent and deputy-regent candidates or candidates for mayor and deputy mayor with the opponents of empty boxes.

\section{RESEARCH METHOD}

The development of alternatives to resolve dissatisfaction with the results of Jepara and Pati regional elections by gathering information from prospective regents, succeeding teams, supporting parties, KPU (General Election Commission), Panwaslu (Election Supervisory Committee) and community groups as input in making policy. Alternative development shows that there are activities to determine alternative policies that can solve the problem. The determination of the policy is based on information and sources that have been obtained. Sources of information obtained about dissatisfaction with the results of the elections. This discussion can bring up or give birth to the development of policy alternatives that make the democratization process more successful. The election process begins with voter data collection, which is to encourage democratization in the organization of the elections. Population growth is needed to be forecasted to support problems in following up on the elections. This research will predict the population in Pati Regency in the next five years. Forecasting is predictive of circumstances based on past trends, assuming that the future has the same pattern as the past. Nawawi (1993)

Public policy analysis is the relationship between the components of policy information and policy analysis methods that provide the basis for distinguishing three forms of policy analysis, those are prospective, retrospective, and integrase analysis Willam and Dunn (2000) . This research uses prospective analysis, which is prediction and transformation of information before policy action begins and its implementation tends to take the way of thinking of 
economists, system analysts and operation researchers Willam and Dunn (2000). A prospective model is a form of public policy analysis that directs its study to the consequences of policies before a policy is implemented. This model can be called predictive because it often involves forecasting techniques to predict the possibilities that arise from a proposed policy. The decision-making theory in this prospective analysis approach is a normative decision theory that provides a basis for improving the effects of a policy. Prospective methods (forecasting or recommendations) are aimed more at practical and direct problem-solving efforts.

Decisions made in this analysis will produce policy recommendations, which aim to provide the most superior policy alternatives compared to other alternatives. In the alternative selection process is based on a clear and transparent set of criteria, so that there is a logical reason, that a policy is chosen or rejected Subarsono (2005). Future policies that can be carried out so that the problems of single pair of leader candidate can be avoided and minimized and can increase the level of participation in elections, i.e. by adopting policies accommodating (1) the need for regeneration of candidate leaders at the party level, (2) the need for policies that can reduce political costs that are too high, (3) law enforcement that needs to be increased so that it will reduce political costs, (4) to lower the standard requirements to be able to run as a candidate for regional leader either supported by political parties, a combination of political parties or from individuals, and ( 5 ) the need for a progressive policy by looking at the situation and conditions in the field.

\section{RESULTS AND DISCUSSION}

\section{Election of Regional Leader with Single Leader Candidate}

The general election to elect a regional leader is an important momentum in the context of forming a government and periodically carrying out the next administration. The implementation of the elections which are expected to run democratically can be seen from the affirmation of the principles of the implementation of elections, i.e. direct, general, free, confidential, honest, and fair. Election of Regional Heads in Pati regency in 2017 was only participated by one pair of candidates for Regent and Deputy Regent, so the election of regent and deputy regent of Pati Regency in 2017 took place between one pair of a candidate with an empty box.

Based on the results of the elections, Pati Regency's General Election Commission (KPU) on 23 February 2017 issued a decree on the determination of the results of the election and recapitulation of Regent and Deputy Regent with Number 16/Kpts/KPU.Kab.Q12.329311/2017 concerning the Determination of the Recapitulation of the Election Result on Regent and Deputy Regent of 2017, which determined that the candidate pair of Haryanto-Saiful Arifin won the most votes. The election results through the decision of the General Election Commission (KPU) of Pati Regency showed that the candidate pair of Haryanto-Saiful Arifin, who fought with empty boxes/columns won the election, i.e. obtaining 519,675 votes or $72,95 \%$ of 712,421 votes, while empty columns/boxes gained 177,762 votes (27.05\%).

However, the victory got resistance from the empty box volunteers, who assumed the victory of the candidates for Regent and Deputy Regent were obtained because of fraud, i.e. the existence of the deployment of the State Civil Apparatus (ASN) and alleged money politics, so that empty box volunteers made a lawsuit over the results of the election.

The decision made the volunteer of the empty box, namely Pati's Community Movement Advocacy Team (Geram Pati) submit a petition to cancel the decision of the Election Commission/Independent Commission for Pati Regency Election Number 16/Kpts/KPU.Kab.Q12.329311/2017 concerning the Determination of the Recapitulation of the Results of the 2017 Regent and Deputy Regent's Election on February 28, 2017. The Pati Community Movement Advocacy Team (Geram Pati) viewed that the Constitutional Court (MK) has the authority to examine and adjudicate cases in the final stage of vote determination in the election of regent and deputy regent until the establishment of a special judicial body as stipulated in Article 157 paragraph (3) of Act Number 102016.

The Advocacy Team- Geram Pati submitted a petition related to a dispute over the final stage of the vote acquisition results for the Regent and Deputy Regent candidates. The legal status of 
Pati's Geram Advocacy Team is in accordance with Article 2 letter a and Article 3 paragraph (1) of Constitutional Court's Regulation Number 1 of 2016 concerning Guidelines for Procedure in Cases of Dispute over Results of the Elections of Governor, Regents and Mayors as amended by the Constitutional Court's Regulation Number 1 of 2017 concerning Amendments to the Constitutional Court's Regulation Number 1 of 2016.

The submission was also based on the decision of KPU/KIP Pati Regency Number 48/ Kpts/KPU.Kab.012.329311/2016 concerning the Determination of Pati's Election on Regent and Deputy Regent in 2017 dated 25 October 2016 explaining that there is only one candidate for regent and deputy regent of Pati. This candidate pair was proposed by PDIP, Gerindra, Democrats, PKB, Golkar Party, PKS, Hanura, and PPP. The Petition of Geram Pati was based on Article 1 number 4 of the Constitutional Court's Regulation Number 3 of 2017 concerning Amendment to the Constitutional Court's Regulation Number 3 of 2016 which states that the petitioner is a pair of candidates for governor and deputy governor, a pair of candidates for regent and deputy regent, or a pair of candidates for mayor and deputy mayor, as well as domestic election observers who are registered and obtain accreditation from KPU/KIP of Province/Regency/District who submit petition for disputes over election results. The Petitioner, Geram Pati, is a community consisting of a number of civil society organizations of Pati Regency, i.e. Alliance of Regional Leader Election Democracy Watch (AKDPP), Communication Forum for Democracy Enforcement of NGOs, and a number of individuals, as well as sympathizers of empty box alliances from around 406 villages, 21 sub-districts in Pati Regency.

In accordance with Article 158 of Act Number 10 of 2016 junction Article 7 of PMK Number 1 of 2016 as amended by PMK Number 1 of 2017, the petitioner submitted a petition for cancellation of the Final Stage of Voting Results for the Election of Candidates for Regent and Deputy Regent by the KPU/KIP of Pati Regency considering that a part of the society do not get their rights as citizens, especially choosing a leader who is not in accordance with my wishes and some people (Sn/initials, 2018, 2019). The submission of the petition for cancellation of the final stage of vote determination in the election results for the Regent and Deputy Regent Candidates of Pati Regency takes into account several provisions. Among other things, the number of residents in the district of the petitioner as candidate pair or election supervisor in the case of one candidate pair, the maximum percentage of vote difference between the petitioner and the candidate pair that wins the most votes based on the determination of the vote count result by the respondent is under one percent. Although based on the official calculation of Pati Regency's Election Commission, the difference in votes was found to exceed two percent of the total population, but the practice of structured, massive and widespread fraud allegedly committed by a single candidate pair must be the main consideration of the Constitutional Court to accept the petition of Geram Pati.

The cheating practice found by Geram Pati was that it allegedly involved various parties which should not be allowed, for example the prohibition by the police towards the activities of Empty Box supporters, the activity prohibition and seizure of properties by Satpol PP (Municipal Police Force), manipulation of number of reports, giving permit to the reported party to withdraw reports against it, mobilizing civil servants to be present in the debate of regent candidate that was thought to have been done by Panwaslu (Election Supervisory Committee) and Panwascam (Sub-district Supervisory Committee) and the partiality of KPPS (Polling Station Working Committee) in the D-day of the election.

The petitioner formally did not get accreditation from the Commission of General Election (KPU) as an official observer. However, its existence and activities to encourage the process of democratization, as well as an honest and fair election, had received recognition both from the community locally and nationally. The Alliance also succeeded in gathering evidence of fraud and election violations in all electoral districts (DAPIL). That the petitioner's non-registration as an accredited election observer was also caused by the Pati Regency's Election Commission which was allegedly not accommodative to the petitioner who wished to register as an election observer in Pati Regency. This was confirmed by the incident when the petitioner wanted to register to be an election observer, it was not well served. The petitioner was only required to visit the KPU's website of Pati Regency. In fact, based on the announcement of KPU-Pati Number 526/KPU.Kab.012.329311/IX/2016 Regarding the Registration Revision of the Domestic Mon- 
itoring Institution for the Election of Regents and Deputy Regents in 2017 dated September 9, 2016, number 1, it clearly stated that the submission of the election monitoring forms can be done in the KPU-Pati.

To encourage the process of democratization and honest and fair elections in Pati Regency, the petitioner had conducted democratic education in form of socialization of the 2017 Regional Leader election (Pilkada), monitoring the election regulations, conducting public discussions with citizens for monitoring the 2017 elections, but it had been often considered to be in a violation. The activities carried out by Geram Pati were forced to disband and were prohibited from doing activities and the destruction of properties. This resulted in the loss of the right of the petitioner to gather, deliver opinions, and provide information to the public, and made it difficult for the public to monitor the pre and current activities during the five-year democratic party process.

During the process or stages in the elections, the petitioner witnessed and received reports from members of the community who have the right to vote that they had witnessed and obtained evidence of various violations and crimes during the campaign period and during the election in which there had been allegations of money politics. This alleged money politics had been reported to Panwaslu (Election Supervisory Committee) of Pati. Monitoring and activities carried out by the petitioner was a form of a resurrection of citizens and accountability for the success of honest and fair elections. Therefore, the petitioner has met the qualifications as an election observer as regulated in PMK No. 1 of 2017 and other applicable laws and regulations. The team of Geram Pati suspected that the determination of the results of the vote count by the KPU that Haryanto-Saiful Arifin won 519,675 votes and the empty column won 177,762 votes from a total of 697,437 valid votes was due to allegations of fraud that were carried out in a structured, systematic and widespread manner. This situation does not necessarily provide a guarantee for a person or group of people to be able to represent an organization that is recognized by applicable laws and regulations. As a result, the vote of the empty box is not guaranteed its right to participate in the calculation.

Geram Pati suspected that there were additions of votes from other candidate pairs in some polling stations. It was done by voting for ballots that were not used by voters because they had not get an invitation to vote. There was an allegation of intimidation to the activists of the Empty Box Alliance and supporters and sympathizers of the Empty Box, such as terror in form of a siege on one of the residents' houses. It was the failure of Panwaslu (Election Supervisory Committee) as a formal institution to monitor elections and follow up on citizens' reports. It was reported that there was an allegation of cheating, intimidation, vandalism and money politics. Alleged money politics is found in all electoral districts. There was an invitation letter for voters who were not distributed by KPPS and the vote is illegally punched by the committee, and this will certainly benefit the existing candidate pairs (Sn, 2018, 2019)

Geram Pati submitted its claim to the Constitutional Court in form of granting the petition of the petitioner entirely, canceling the Decree of Pati KPU Number 16/Kpts/KPU.Kab.012.329311 / 2017 dated February 23, 2017. The Geram Pati's request was for the Constitutional Court's Judge to determine the vote acquisition of the Regent Candidate Election and the Deputy Regent of Pati in 2017, according to the applicant, the candidate pair Haryanto-Saiful Arifin received 300,000 votes and the Empty Column 700,000 votes from 1,030,676 voting rights. The Court is also expected to order the KPU of Pati Regency to implement the decision.

Allegation of structured, massive and widespread fraud was in the form of police involvement that prohibits activities. Satpol PP (Municipal Police Force) also prohibited and seized the properties of Geram Pati. Panwaslu and Panwascam were allegedly related to manipulating the number of reports and allowing the reported party to retract the report. Another practice that was suspected was mobilizing civil servants. Some of them attended the Regent Candidate's debate. Besides, there were KPPS's alignments when voting. "There is a tendency for security forces to support candidate pairs" (Sn, 2018 and 2018). For the lawsuit from volunteers of the empty boxes/columns to the General Election Commission (KPU) of Pati regency in the Constitutional Court, it was finally won by the KPU and determined the election victory was the pair Haryanto-Saiful Arifin. With the decision of the Constitutional Court, the General Election 
Commissioner (KPU) of Pati stated that the Constitutional Court's decision was appropriate, because the KPU had socialized the existence of a single candidate and empty column in accordance with applicable regulations, so it could not be said that the party that did not support the existing Regent/Deputy Regent candidates (supporters of the empty box) were not accommodated (Sn, 2018, 2019).

I'm, a staff member of the Election Supervisory Committee (Panwaslu)-Pati stated that the authority of Panwaslu has been added, so it needs support from the community so that when reporting it must be accompanied by evidence. The public need not be afraid to report suspected violations (Lev, 2018, 2019).

Next Jn, Spokesperson for regent candidate of Pati stated that the existing rules were good. Likewise En, the succeeding team of Pati regent candidate (who was declared victorious) stated that the regulation regarding the election of regent or deputy regent against empty boxes has been clear (En, 2018, 2019).

Based on the collected data and its analysis, it can be seen that the volunteers of the empty boxes who submitted objections or petitions to the Constitutional Court on the decision of the KPU of Pati were due to allegations of election violations. The violation occurred when, for example, the police forbade the activities of the Empty Box's supporters, Satpol PP (Municipal Police Force) carried out the prohibition and seizure of properties, Panwaslu and Panwascam were related to manipulating the number of reports, allowing the reported party to retract reports against it, mobilizing civil servants to be present in the debate of regent candidate and the partiality of KPPS on the D-day of the election. Petition for cancellation of KPU's decision at the Constitutional Court is in the context of maintaining the democratization of the elections.

\section{Prospective Public Policy in the Sector of Regional Leader Election}

The election of regional leader in Pati regency began with the Permanent Voter List (DPT) established by the General Election Commission (KPU) of Pati Regency on December 6, 2016 with Number 95/BA/KPU-Pati/ XII/2016 concerning Open Plenary Meetings for Recapitulation of Provisional Voters Improvement Results (DPSHP) and Determination of Permanent Voter List (DPT) for the Election of Regent and Vice Regent in Pati Regency in 2017, amounting to 1,034,256 (one million thirty-four thousand two hundred fifty-six) voters. The next stage is that a political party or a combination of political parties can register or promote prospective candidates for regent and deputy regent by having a minimum of $20 \%$ of the total number of the Regional House of Representative (DPRD)'s results of the 2014 election of Pati Regency that is at least 10 (ten) seats in the DPRD or at least $25 \%$ from the accumulation of valid votes for the 2014 election, which is at least 179,449 valid votes. The candidate pairs from individuals must be able to meet the minimum 6.5\% requirement of the total number of voters in the 2014 presidential and vice-presidential election in Pati Regency, which is 67,015 people with the spread of supporters in at least eleven districts. On September 22, 2016 at 10:00, a combination of eight political parties registered Hariyanto as a potential candidate for regent and Saiful Arifin as a candidate for deputy regent, all were received by the chairman and all members of the KPUPati. The eight parties consisted of PDIP (8 seats), Gerindra (8 seats), PKS ( 5 seats), Democrats (6 seats), Golkar (6 seats), Hanura (4 seats), PPP (3 seats), and PKB (6 seats) chair). Until the deadline for registration, there was only one candidate pair that was promoted by a political party or a combination of political parties.

The KPU of Pati on September 24, 2016 made a stance by stipulating Decree Number 41/ Kpts/KPU. Kab.012.329311/2016 concerning the postponement of the election stages for the Regent and Deputy Regent in 2017. The postponement of the election stage letter was followed by a decision letter for the Pati Regency number 42/Kpts/KPU.Kab.012.329311/2016 amendments to the three decisions of KPU-Pati Regency number 05/.Kpts/KPU.Kab.012.329311/2016 concerning technical guidelines, stages, programs, and schedule for holding the 2017 election of Regent and Vice Regent. Regulation for postponing and extending the registration of candidate pairs was outlined in the KPU's letter No. 533/KPU/IX/2016 as follows. On September 26, 2016, the KPU established a delay in the election stages. From 26 to 28 September 2016 is the 
socialization of the delay and extension of the registration of candidate pairs. From September 29 to October 1, 2016 is the registration of candidate pair.

In KPU's letter No. 533/KPU/IX/2016 it was regulated that if in one region there is 1 (one) pair of candidate who has registered during the registration period of 21 to 24 September 2016, while a political party or several other political parties have not registered, the acquisition of a minimum seat get $20 \%$ or $25 \%$ of votes, then other candidate pairs can register through a political party or a combination of different political parties. If there are individual candidates who have submitted requirements and administrative and factual research but have not registered on 21 to 24 September 2016, they can register during the renewal period. The result of the study of candidate requirements through Pati Regency KPU's letter No. 620/KPU. Kab. Pati. 012.329311/X/2016 dated 11 October 2016 was notified to the leaders of the political parties bearing the prospective candidates for Regent and Deputy Regent of Pati Regency. The result of the research on the candidates' requirements was presented in a plenary meeting attended by the leaders of the political parties, the campaign team, and related institutions.

Hariyanto and Saiful Arifin were determined as candidates for regent and deputy regent based on the result of the first and second stages of research on fulfilling the requirements for prospective regent and deputy regent with KPU-Patis decree number 48/Kpts/KPUKab.012.329311 / 2016. Then the Election Commission (KPU) of Pati Regency determined that the election of regent and deputy regent of Pati Regency was only followed by one pair of Pati Regent and Deputy Regent candidates of 2017 with the KPU's Decree number 49/Kpts/KPU-Kab 012.329311/2016. The determination of the candidate pairs for Pati's Regent and Deputy Regent of 2017 was announced by the Pati Regency's KPU through the KPU's website, announcement boards, and mass media. The determination of Regent and Deputy Regent candidates of Pati 2017 was based on Pati Regency KPU's Decree Number 49/Kpts/KPU-Kab $012.329311 / 2016$ on October 24, 2016 with no party submitting a petition of the dispute to the Central Java Provincial Election Supervisory Body or Pati Regency's Election Supervisory Committee.

With the appointment of the regent/deputy regent candidate, the next step is that the KPU regulates the voter candidate campaign, meaning the regional leader candidates cannot be free to carry out the campaign. Matters arranged in a campaign such as campaign properties, campaign sites, and campaign schedules. Candidates for a regional leader cannot just post pictures on the roadside or advertise in mass media, all are limited and regulated by the KPU. The circumstance made the election less lively because the level of splendor can actually boost public participation. The community does not have the opportunity to choose other potential pairs, so that community participation can be reduced, then the community will prefer to go to work. Moreover, the voting schedule is also not well known. Therefore, to encourage voter participation, the KPU continues to disseminate information to the public, whether through religious institutions, organizations, community groups, and education. Even, the Friday sermon text was also made for preachers.

Ahead of the voting, the invitation was sent by KPU through KPPS. The invitation was in accordance with the number of DPT. Each KPPS goes to the voter candidates. However, there were invitations that were returned because of double voters, voters had moved their addresses, voters had died, and did not match the voter's name. The socialization and campaign of the election of 2017 in Pati Regency had been done as conducted by the KPU of Pati Regency in person or in collaboration with the community, relevant agencies, mass organizations, political parties, media, and various NGOs in Pati Regency. The forms of socialization carried out by KPU are socializations (1) about the stages and budget for the election of the Regent and Deputy Regent of Pati Regency in 2017, (2) about the nomination procedures and nomination requirements, (3) to disabilities, (4) through a discussion about democracy with public figures, (5) for women's groups, (6) in tertiary institutions, (7) with novice voter groups, (8) with the leaders of Pati Regency's Muhammadiyah, and (9) with leaders of Nahdhotul Ulama-Pati. The socialization was also carried out with traditional art performances held in various sub-districts, healthy walk event, talk shows on radio and television, Friday sermons, traveling cars, collaboration with third parties (universities, schools), socialization in the level of district and village as well as the distribution of props. 
The KPU of Pati Regency had facilitated campaign props that have been distributed consisting of vision and mission banners, banners and banners. The KPU of Pati also monitored the campaign in form of monitoring the implementation of the consolidation and inauguration of the Hariyanto-Saiful Arifin success team at the village level throughout Pati Regency and monitoring the implementation of the rally campaign in the yard of Joyo Kusumo Stadium with 6,000 sympathizers of candidate pairs. The next stage was the implementation of Regent and Deputy Regent elections in Pati Regency which proceeded according to the stages that had been scheduled by the KPU of Pati, which was conducted simultaneously on February 15, 2017 with a total of 2,295 polling stations scattered in 406 villages and 21 subdistricts. The flow of realizing government from the people, by the people, and for the people, is no longer unstoppable. The community's participation in the implementation of the election was without any intervention from anyone, there was a freedom to choose a candidate for the head of the region, even be elected as a leader. This was shown by the high desire of citizens involved in the event of the elections, the level of community participation in Pati's Pilkada (Regional Election) reached 68.7 percent. Pilkada's implementation policies in Pati regency were tried to be analyzed using a prospective analysis model which is a form of policy analysis that directs its study to the consequences of policies before a policy is implemented. This model can be called a predictive model because it often involves forecasting techniques to predict the possibilities that arise from a policy that will be proposed Suharto (2005). Decisions to be taken in this analysis will result in policy recommendations.

The discussion on forecasting is a crucial thing in discussing public policy because from forecasting it will be known what kind of social, economic, and political conditions in the future, then intervention can be made through government policy. Forecasting is to determine factual information about future situations based on current information. By the data above and the high level of community participation with single pair candidates (68.7 percent) and by using linear regression, the estimated voter participation in the Pati Regency's elections in 2023 will increase reaching 87.676 percent. It means that in the next five years there will be a significant increase in voter participation along with the increased socialization by the KPU and related institutions and election participants. This increased participation will encourage the level of democratization in general elections and the election of regional heads or regents. The result of these calculations can be used to develop alternative policies in the next period. Policy alternatives can be obtained by gathering information and sources related to the problem being studied. The existing alternatives are to see how the best approach to the problem at hand is having a single pair of leader candidates.

\section{CONCLUSION}

Based on the data obtained and the analysis carried out, it can be concluded that the volunteers of the empty boxes who filed objections or petitions to the Constitutional Court on the decision of the General Election Commission (KPU) of Pati Regency were due to allegations of election violations. The violation occurred when, for example, the police forbade supporting activities in the Empty Box, Satpol PP (Municipal Police Force) carried out the prohibition and seizure of props,

Panwaslu (Election Supervisory Committee) and Panwascam (Sub-district Election Supervisory Committee) related to manipulating the number of reports, allowing reported parties to retract reports against it, mobilizing civil servants to be present in debates of regent candidates and the partiality of KPPS in the D-day of the election. Request for cancellation of the KPU's decision at the Constitutional Court was in the context of maintaining the democratization of the regional elections. Future policies that can be carried out so that the problems of potential single pair of leader candidates can be avoided and minimized and can increase the level of participation in the elections, i.e. to take a progressive legal policy by looking at the conditions that occur in the field. By analyzing the prospective policy model, the process of democratization can be improved. 


\section{ACKNWOLADGMENT}

Thank you to the JKMP journal manager for publishing this manuscript.

\section{REFERENCES}

Danielle, M. P. D. D. and Vogenbeck (2014). Ilmu Kebijakan di Persimpangan Jalan, dalam Handbook Analisis Kebijakan Publik (Bandung: Nusamedia).

Fischer, F., Miller, G. J., and Sidney, M. S. (2007). Handbook of Public Policy Analysis: Theory, Politics and Methods (Boca Raton: CRC Press).

Nawawi, H. (1993). Metode Penelitian Bidang Sosial (Yogyakarta: Gadjah Mada University Press)

Sofyan, S. (2013). Permasalahan dan Solusi Pemilukada http://www.lemhannas.go.id/portal/in/daftar-artikel/ 1634-permasalahan-dan-solusi-pemilukada.html.

Subarsono, A. G. (2005). Analisis Kebijakan Publik (Yogyakarta: Pustaka Pelajar).

Suharto, E. (2005). Analisis Kebijakan Publik Panduan Praktis Mengkaji Masalah dan Kebijakan Sosial (Bandung: Alfabeta).

Torgerson, D. (1986). Between Knowledge And Politics: Three
Faces Of Policy. Policy Sciences 19.

Willam, N. and Dunn (2000). Analisa Kebijakan Publik (Yogyakarta: PT Hadinindita Graha Widya).

Conflict of Interest Statement: The author declare that the research was conducted in the absence of any commercial or financial relationships that could be construed as a potential conflict of interest.

Copyright $(2020$ Suparnyo. This is an open-access article distributed under the terms of the Creative Commons Attribution License (CC BY). The use, distribution or reproduction in other forums is permitted, provided the original author(s) and the copyright owner(s) are credited and that the original publication in this journal is cited, in accordance with accepted academic practice. No use, distribution or reproduction is permitted which does not comply with these terms. 